\title{
DIGITAL IMAGE CORRELATION SYSTEMS IN THE EXPERIMENTAL INVESTIGATIONS: CAPABILITIES AND LIMITATIONS
}

\section{KRAWCZYK ${ }^{1}$, MICHAL GOLDYN ${ }^{2}$, TADEUSZ URBAN ${ }^{3}$}

\begin{abstract}
The aim of the paper is to present the possibilities and limitations of using the Digital Image Correlation systems. In order to assess the measurement inaccuracies the measuring volume $1250 \times 1100 \mathrm{~mm}$ was analysed using two cameras with sensor resolution 6 megapixels. It was stated very good accuracy of the line segment length change. It causes that observation of crack widths can be considered as precisely. Some practical information concern how determine the compatibility between crack width measured traditionally and by using DIC are given. In the second part of the paper the results of the tests concerning capacity of interface between two concrete casting at the same time were presented. Use of the optical measurement system Aramis enables the analysis of the deformation, determination of failure mode of the tested specimens and limit displacement between edges of the interface.
\end{abstract}

Keywords: Digital Image Correlation System, concrete structures, measuring systems

\section{INTRODUCTION}

Modern measuring devices became more popular, one type of them is Digital Image Correlation system (DIC). That kind of tools gives new research capabilities. Using DIC during the test is much safer, because testing element is observed from a distance. It is important especially if sudden failure is expected. Besides indubitable advantages, using DIC is connected with limitations, which are

\footnotetext{
${ }^{1}$ PhD., Eng., Lodz University of Technology, Faculty of Civil Engineering, Al. Politechniki 6, 90-924 Lodz, Poland, e-mail: lukasz.krawczyk@p.lodz.pl

${ }^{2}$ PhD., Eng., Lodz University of Technology, Faculty of Civil Engineering, Al. Politechniki 6, 90-924 Lodz, Poland, e-mail: michal.goldyn@p.lodz.pl

${ }^{3}$ Prof., DSc., PhD., Eng., Lodz University of Technology, Faculty of Civil Engineering, Al. Politechniki 6, 90-924 Lodz, Poland, e-mail: tadeusz.urban@p.lodz.pl
} 
specified in the paper. Measuring errors of strains under some conditions could represent an order of magnitude for ultimate concrete strain. Examples of experimental investigations of concrete structures conducted in Department of Concrete Structures of Lodz University of Technology $[1 \div 3]$, by authors are presented in the paper. Discussion of obtained results can be used by other researchers to make interpretation of their experiments easier.

\section{UNCERTAINTY ANALYSIS}

Essential issue is to determine the uncertainties of measurements. It is very complex task, for analytical approach. Kneć [4] and Revilock at al. [5] keep a record of measurement noise then they deduced about inaccuracies. That method requires to take many photos of surface. It is assumed that unloaded specimen, not subjected to temperature changes should look identically in the each image. If any changes are observed they are classified as measurement noise. That procedure can be easily make and all impacts are considered. Very important is to keep constant light condition during the test.

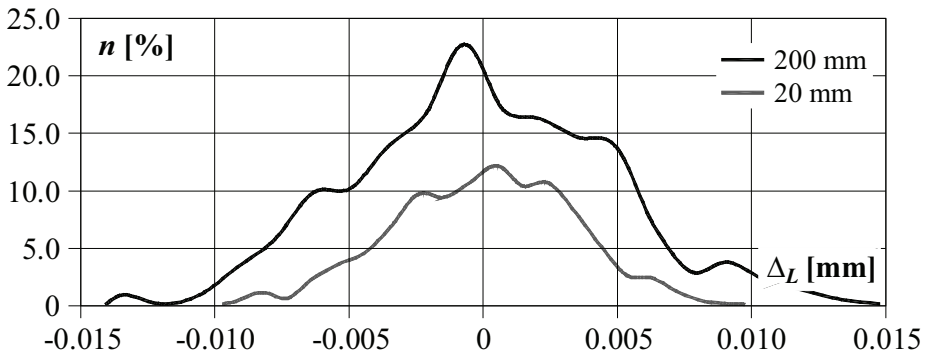

Fig. 1. Deviation of length of virtual measuring bases and frequency of its occurrence - base length $20 \mathrm{~mm}$ and $200 \mathrm{~mm}$ (unloaded specimen).

In order to determine inaccuracies 400 measurements (800 pictures) of surface have been made. Deviation value and frequency of its occurrence are presented in Fig. 1 (length) and in Fig. 2 (strain). The readings from $-0.013 \mathrm{~mm}$ to $+0.013 \mathrm{~mm}$ for $200 \mathrm{~mm}$ and from $-0.009 \mathrm{~mm}$ to $+0.008 \mathrm{~mm}$ for $20 \mathrm{~mm}$ base were recorded. Statistical analysis for that data were made. Standard errors were calculated. Their value are equal to $0.005 \mathrm{~mm}$ and $0.003 \mathrm{~mm}$ for longer and shorter base, respectively. These measurements can be considered as precise - the typical scale division for optic compactor is $0.05 \mathrm{~mm}$. 


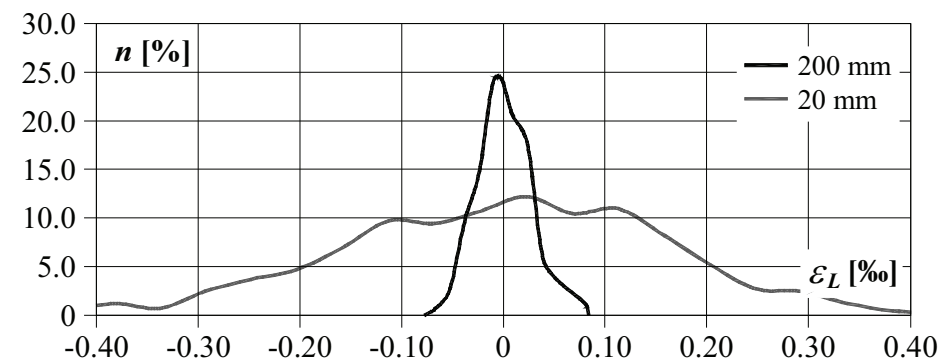

Fig. 2. Deviation of strains for linear measuring bases and frequency of its occurrence - base length $20 \mathrm{~mm}$ and $200 \mathrm{~mm}$ (unloaded specimen)

The linear strains can be also measured by using Digital Image Correlation. Noise values for strain are in range from $-0.068 \%$ to $0.068 \%$ or $200 \mathrm{~mm}$ and from $-0.441 \%$ to $0.363 \%$ or $20 \mathrm{~mm}$ base. The standard errors values are $0.024 \%$ and $0.150 \%$. The longer base the smaller error is. Both values are much higher than error of strain gauges.

\section{MEASUREMENTS OF CRACK WIDTH}

Measuring crack width is possible by using Aramis system. However it is not easy to make it properly. Aramis creates maps where accumulation of strains can be find - regions where the cracks are occurring. The way of determining the crack width is presented in an example of corbel tested in Lodz. In the Fig. 3b measuring bases for crack 3 and 3' are presented. It was initially assumed that anchor points of measuring base should be outside of the strain accumulation area (crack 3 ). It is according to the method presented by Goszczyńska et al. [6] or Goszczyńska and Tworzewska [7]. Authors stated that discussed approach gives higher width of crack than values obtained using optical compactor (3 opt.) - see Fig. 3a. It was found that measurements carried out by using base (Crack 3') ensure good compatibility with measurement ( 3 opt.). In the presented example length of strain accumulation area is about $42 \mathrm{~mm}$ while the dimension of the (Crack 3') base is only $12 \mathrm{~mm}$. 


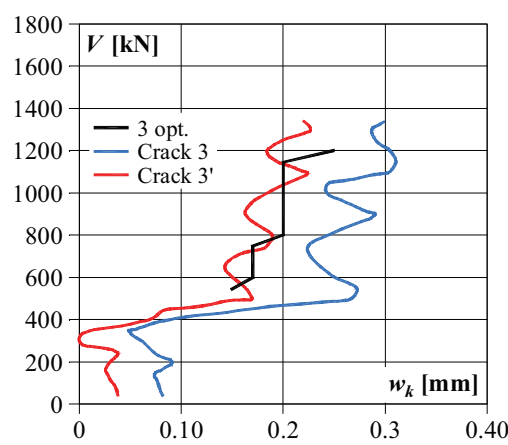

a)

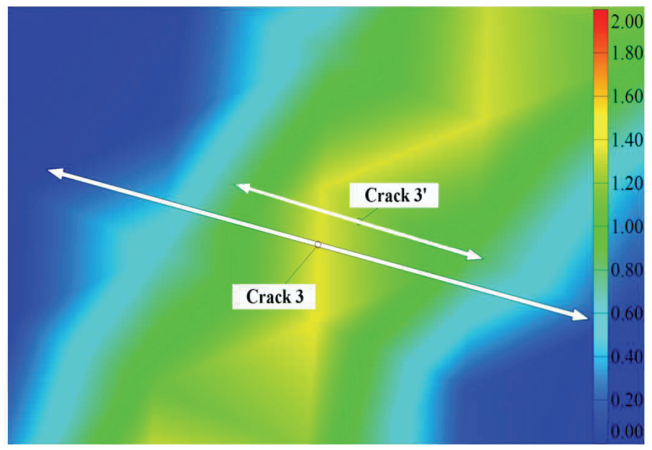

b)

Fig. 3. Crack no. 3 a) comparison of crack widths measured traditionally (3 opt.) and by Aramis,

b) measuring bases used by Aramis: (Crack 3) and (Crack 3')

For correct measurements of crack width reference length of base have to be found. It is easy to have correct results if some optical measurements for chosen load level are made. It is necessary to find length of base which gives values similar to reference value, then the rest of the results will be trustworthy.

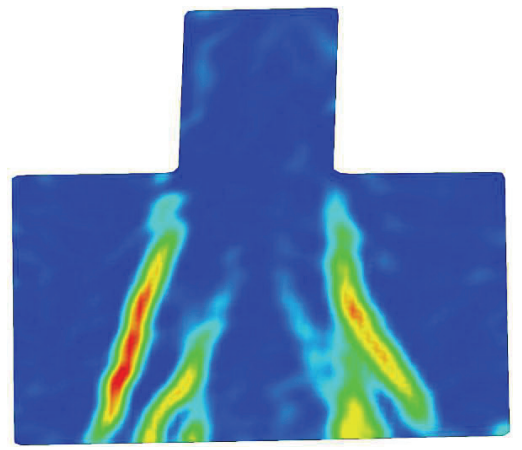

a)

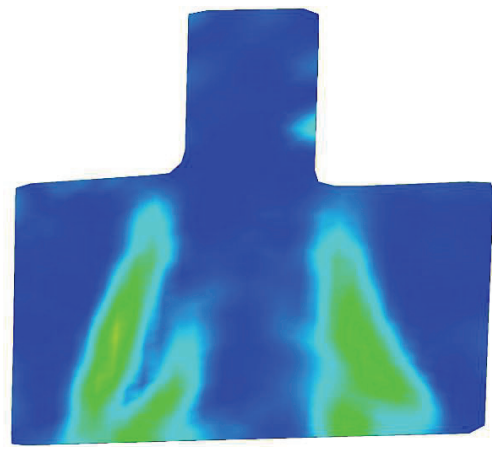

b)

Fig. 4. Comparison of principal strain maps for corbel E - II at load equal to $1000 \mathrm{kN}$. Surface divided into facets a) $15 \times 15$, b) $45 \times 45$

Measurements provided by using Digital Image Correlation are possible by dividing the test surface into fixed-size fields called facets. The standard facet features is $21 \times 21$ pixels. Based on the comparison between reference image and images recorded during the test it is possible to determine 
the displacement of selected points on the surface. On this basis, the deformation can be calculated. The facet density affects the results in a manner analogous to the grid of the finite element method. To illustrate this phenomenon two different sizes of facets were considered: $15 \times 15$ and $45 \times 45$ pixels. The image of major deformation of the E-II corbel for the dense and thinning arrangement of facets is shown in Fig. 4. The deformation maps refer to the same element at a load level of $1300 \mathrm{kN}$. Comparing Fig. $4 \mathrm{a}$ and $4 \mathrm{~b}$, it can be stated that for larger facets, the features of the cracks were considerably more blurred and the deformation images were less detailed.

\section{DIC IN THE TESTS OF SPECIMENS SUBJECTED TO SHEAR CUTTING}

The investigations were intended to qualitatively assess the problem of shear cutting of concrete. This phenomenon can occur for elements with low shear slenderness $\lambda=a_{c} / h$ (where $a_{c}$ is the distance between point of load and the edge of the support and $h$ is the height of the element) such as very short reinforced concrete corbels. For this purpose, three "Z" shaped specimens made of the same concrete as a whole, were tested - see Fig. 5. The only variable parameter was the area of reinforcement transverse to the contact surface $\left(A_{s w}\right)$. During loading the images were recorded by using cameras included in the Digital Image Correlation system Aramis (10 frames per second). The load was increased gradually at $30 \mathrm{kN}$, however at higher load level (about $60 \div 70 \%$ of ultimate load) the force was applied in uniform manner.
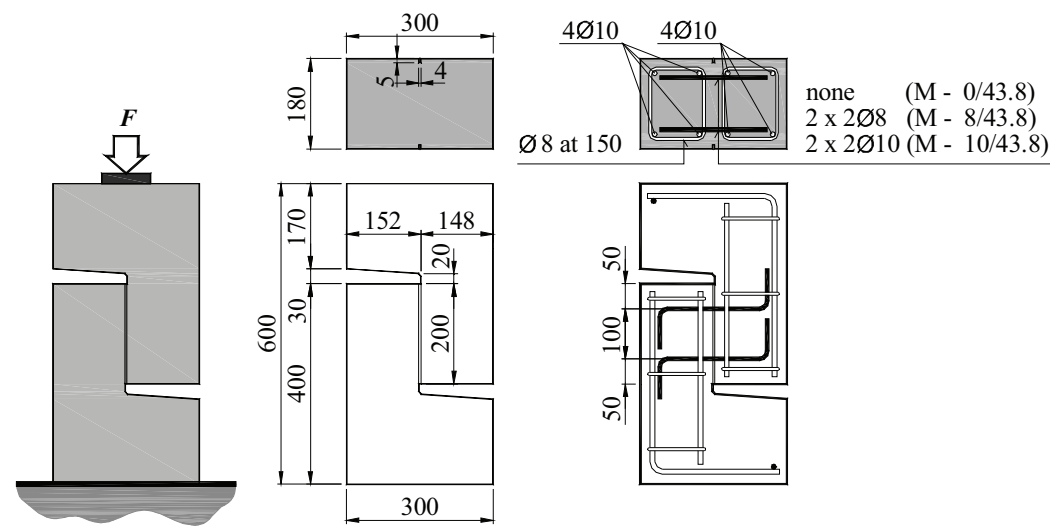

Fig. 5. Dimensions, shape and reinforcement of the test specimens 
The use of the DIC system ARAMIS enabled for accurate registration of the destruction process in case of all models. The failure of $\mathrm{M}-0 / 43.8$ specimen with unreinforced interface was violent. The splitting of the element occurred within $0.1 \mathrm{~s}$ and was preceded by the appearance of a vertical crack, visible in Fig. 6.

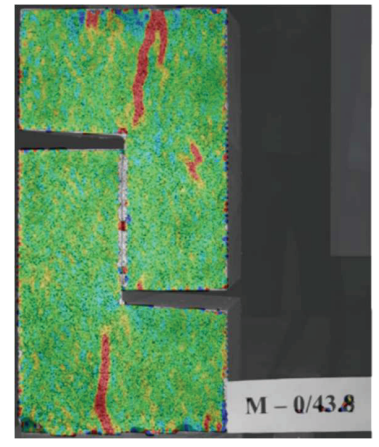

$0 \mathrm{~s}$

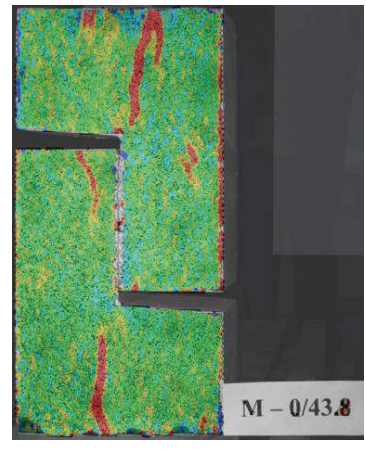

$0.1 \mathrm{~s}$

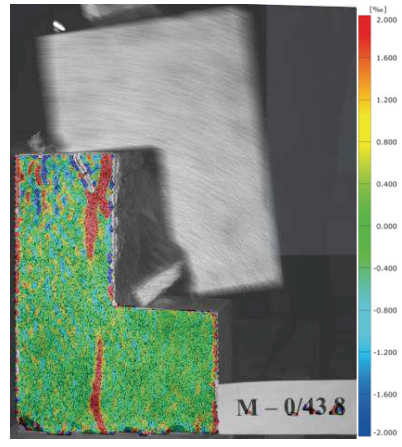

$0.2 \mathrm{~s}$

Fig. 6. Course of destruction of $\mathrm{M}-0 / 43.8$ specimen (at load of $198.6 \mathrm{kN}$ )

Analysis of the strain maps based on recorded images allowed the qualitative assessment of the distribution of internal forces within the elements. Maps of deformation fields made possible to indicate the potential cracked zones and to determine the probable course of cracks. Comparing Fig. $7 \mathrm{a}$ and $7 \mathrm{~b}$ with Fig. $7 \mathrm{c}$ a clear correlation between the zones of tensile strain accumulation (marked with red) and the cracks indicated during the tests can be seen. In the middle of the interface the compressive stress pass from one part of the element to the other. This is accompanied by the splitting forces visible on the maps of horizontal strains. Zones of tensile strain accumulation, visible in internal part of specimens, resulted from pulling as well as bending of transverse reinforcement (kinking effect).

The differences between the extent of the cumulative deformation zones and the course of the cracks marked during the test were due to the accuracy of human eye. The Digital Image Correlation allowed for much earlier prediction of zones of expected cracking.

Due to the lack of interface reinforcement and stress acting perpendicular to the contact surface, the load carrying capacity of the $\mathrm{M}-0 / 43.8$ specimen was dependent solely on the adhesion forces. Their disappearance was violent and occurred when the mutual movement of the edges of the interface was about $0.15 \mathrm{~mm}$. Such displacement was about three times higher with respect to values recorded during the tests conducted by Randl and Wicke [8] who concerned interfaces between concrete cast at different times. 


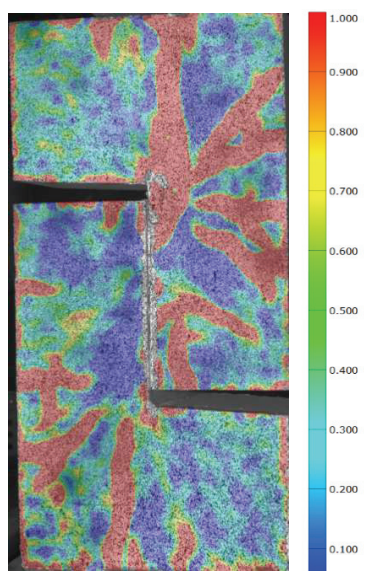

a)

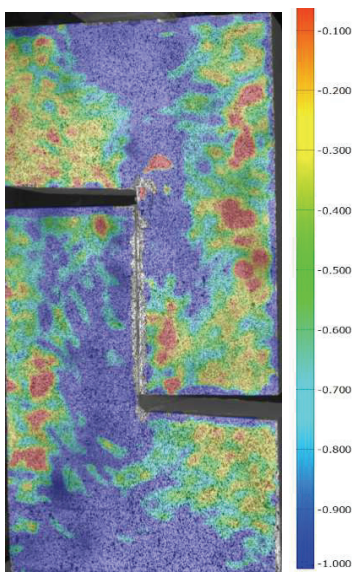

b)

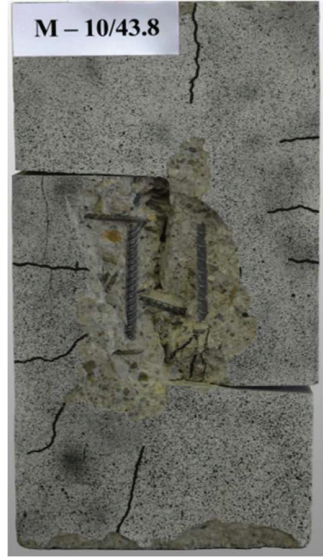

c)

Fig. 7. Specimen $M-10 / 43.8$ : a) major strains, b) minor strains recorded before failure, c) front view after failure
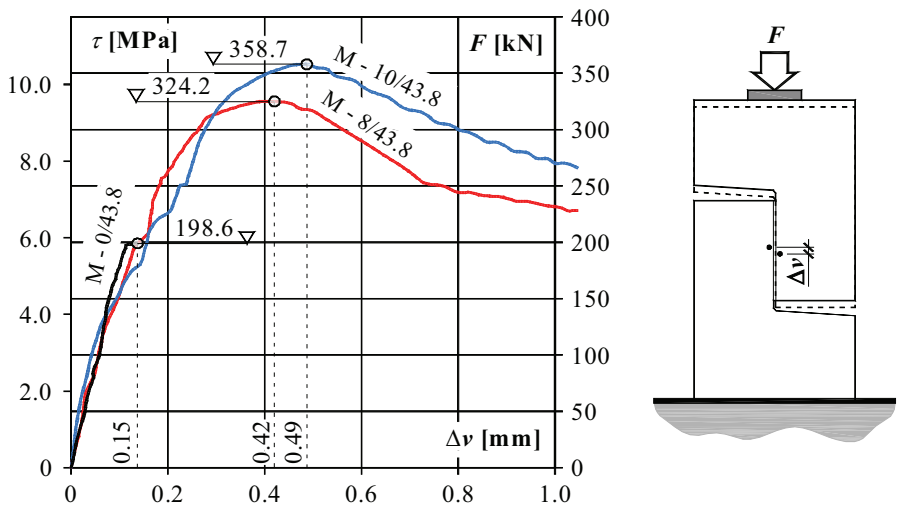

Fig. 8. Comparison of the mean displacements between edges of the interface

The introduction of transverse reinforcement made it possible to change the mechanism of interface failure - from brittle to ductile, and at the same time to increase the load capacity by $163 \%$ and $180 \%$ ( $\mathrm{M}-8 / 43.8$ and $\mathrm{M}-10 / 43.8$ respectively) with respect to the reference element $\mathrm{M}-0 / 43.8$. It resulted from two additional mechanisms: aggregate interlock and dowel action that could not work in the case of unreinforced interface. Registered images allowed for accurate determination of the displacements associated with achieving the ultimate load - see Fig. 8. 
At the further stage of the test, intense increase in deformation, which lead to rupture of the transverse reinforcement, was observed. The appearance of each "step" in the load - deformation curves was accompanied by a characteristic thwacks, hearable during the test. This allows to state that the measurements carried out by using the DIC system made possible to determinate accurately the moment of rupture of interface reinforcement.

\section{CONCLUSIONS}

According to results of the tests concerning corbels and " $\mathrm{Z}$ " shaped specimens many advantages of using Digital Image Correlation system can be seen. It enables to determine location of cracks just before the cracks have become visible by human eye, to estimate the width of the cracks as well as to follow the development of model deformation (eg. by using the virtual extensometers). The biggest advantage of using DIC is no need to install the necessary measuring devices before the tests. The analysis of recorded images can be carried out later, when the test is over. The virtual measuring equipment (eg. extensometers) can be placed wherever it is need. The use of the optical measuring device has allowed to record the deformations of $\mathrm{M}-0 / 43.8$ specimen even after the maximum load has been exceeded - without damaging of the transducers as would be in case of direct contact measuring methods.

However, it should be borne in mind that the results of measurements carried out by Digital Image Correlation systems can be flawed. Measurement errors are strongly dependent on the: size of the measuring area, inaccuracies of averaging the results of calculations, light condition changes during the test, noises of digital camera, angle between cameras and analyzed surface, quality of the lenses as well as preparation of the test surface.

\section{REFERENCES}

1. Ł. Krawczyk, "Strenthening of short corbels with embedded through-section reinforcement" (in polish) Doctoral Thesis Lodz University of Technology, Poland, 2017.

2. Ł. Krawczyk, M. Gołdyn, T. Urban, ,About Inaccuracies of DIC System” (in polish) JCEEA: Vol. 64 (3/I/17), 259-270, 2017.

3. M. Gołdyn, Ł. Krawczyk, T. Urban, „Considerations About Carrying Capacity of Elements Subjected to Shear Cutting” (in polish) JCEEA: Vol. 64 (3/I/17), 293-305, 2017,

4. Kneć M., „Technika cyfrowej korelacji obrazów w analizie deformacji połączeń elementów konstrukcji stosowanych w lotnictwie". Doctoral Thesis. RUT, 2015.

5. D.M. Revilock, J.C. Thesken, T.E. Schmidt, B.S. Forsythe, "Three-Dimensional Digital Image Correlation of a Composite Overwrapped Pressure Vessel During Hydrostatic Pressure Test” Technical Report NASA, 2007. 
6. B. Goszczyńska, W. Trąmpczyński, J. Tworzewska, P. Tworzewski, "Doświadczalna analiza odkształceń przestrzennych belek żelbetowych z zastosowaniem skanera optycznego 3D”, Inżynieria i Budownictwo: Vol. 70, No. 3, 156-159, 2014.

7. B. Goszczyńska, J. Tworzewska, “Określenie rysy na potrzeby analizy wyników badania procesu powstawania i rozwoju rys w belkach żelbetowych z zastosowaniem systemu Aramis”, Przegląd Budowlany: Vol. 85, No. 12, 24-29, 2014.

8. N. Randl, M. Wicke, ,Schubübertragung zwischen Alt- und Neubeton. Experimentelle Untersuchungen, theoretischer Hintergrund und Bemessungsansatz“, Beton- und Stahlbetonbau: H. 95, 461-473, 2000.

\section{LIST OF FIGURES AND TABLES:}

Fig. 1. Deviation of length of virtual measuring bases and frequency of its occurrence - base length $20 \mathrm{~mm}$ and $200 \mathrm{~mm}$ (unloaded specimen).

Rys. 1. Wartość rozrzutu długości wirtualnej bazy i czestotliwość ich występowania - baza o długości $20 \mathrm{~mm}$ i $200 \mathrm{~mm}$ (próbka nieobciążona)

Fig. 2. Deviation of strains for linear measuring bases and frequency of its occurrence - base length $20 \mathrm{~mm}$ and $200 \mathrm{~mm}$ (unloaded specimen)

Rys. 2. Wartość rozrzutu odkształceń dla pomiaru na bazie i czestotliwość ich występowania - baza o długości $20 \mathrm{~mm}$ i $200 \mathrm{~mm}$ (próbka nieobciążona)

Fig. 3. Crack no. 3 a) comparison of crack widths measured traditionally ( 3 opt.) and by Aramis, b) measuring bases used by Aramis: (Crack 3) and (Crack 3')

Rys. 3. Rysa numer 3 a) porównanie szerokości rozwarcia rysy mierzonej tradycyjnie (3 opt.) i za pomocą Aramisa, b) bazy pomiarowe użyte przez Aramisa: (Crack 3) i (Crack 3')

Fig. 4. Comparison of principal strain maps for corbel E - II at load equal to $1000 \mathrm{kN}$. Surface divided into facets a) $15 \times 15$, b) $45 \times 45$

Rys. 4. Porównanie map odkształceń głównych wspornika E - II przy sile równej 1000 kN. Powierzchnia podzielona na fasetki a) $15 \times 15$, b) $45 \times 45$

Fig. 5. Dimensions, shape and reinforcement of the test specimens

Rys. 5. Wymiary, kształt i zbrojenie badanych elementów

Fig. 6. Course of destruction of $\mathrm{M}-0 / 43.8$ specimen (at load of $198.6 \mathrm{kN}$ )

Rys. 6. Przebieg zniszczenia elementu M - 0/43.8 (przy obciążeniu $198.6 \mathrm{kN}$ )

Fig. 7. Specimen $M-10 / 43.8$ : a) major, b) minor strains recorded before failure, c) front view after failure Rys. 7. Element $M-10 / 43.8$ : a) maksymalne, b) minimalne odkształcenia główne zarejestrowane przed zniszczeniem, c) widok po zniszczeniu

Fig. 8. Comparison of the mean displacements between edges of the interface Rys. 8. Porównanie średnich przemieszczeń pomiędzy krawędziami płaszczyzny ścinania 


\section{SYSTEMY CYFROWEJ KORELACJI OBRAZU W BADANIACH EKSPERYMENTALNYCH: MOŻLIWOŚCI I OGRANICZENIA}

Slowa kluczowe: systemy cyfrowej korelacji obrazu, konstrukcje żelbetowe, systemy pomiarowe

\section{STRESZCZENIE:}

Celem artykułu jest przedstawienie możliwości i ograniczeń stosowania systemów cyfrowej korelacji obrazu (CKO). W celu oceny niedokładności pomiaru przeanalizowano pole pomiarowe o wymiarach $1250 \times 1100 \mathrm{~mm}$, wykorzystując dwa aparaty o rozdzielczości matryc 6 megapikseli. Stwierdzono bardzo dobrą dokładność wyznaczenia zmiany długości odcinka. Dzięki temu obserwację szerokości rys można uważać za dokładną. W artykule zawarto praktyczne informacje dotyczące tego, w jaki sposób prowadzić pomiar szerokości rozwarcia rys za pomocą CKO. W drugiej części artykułu przedstawiono wyniki badań dotyczących nośności styku elementów betonowanych w tym samym czasie. Zastosowanie optycznego układu pomiarowego Aramis umożliwiło analizę odkształcenia, określenie sposobu zniszczenia badanych próbek i granicznych przemieszczeń między krawędziami połączenia. 